\title{
An Akan (Bono-Twi) Mother-Tongue Commentary on the Second Letter of John
}

\section{Isaac Boheng 1}

1 Department of Biblical and Religious Studies, University of the Free State, South Africa and Christian Service University College, Kumasi, Ghana.

\begin{abstract}
Christianity in Africa has experienced phenomenal growth in recent times. This growth however comes with the challenge of how the African church can maintain its numerical strength and at the same time ensure that the faith of its members is well grounded in Scriptures. One way to respond to this challenge is to provide the church with African-brewed resources for didactic purposes. In such an exercise the role of African mother-tongue biblical hermeneutics and theologizing cannot be overstated. This article is a mother-tongue commentary on the second epistle (letter) of John based on the Bono-Twi text. The second letter of John was chosen because contemporary African society shares relevant aspects of the context of the addressees of this letter. For example, false teachers abound in the African church just as they did in the community to whom this letter was addressed. The BonoTwi text was obtained from the Greek text (Novum Testamentum Graece: Nestle-Aland) through a meticulous application of relevant principles of translation and a careful mediation between the biblical culture and the Akan culture. Afterward, a Bono-Twi commentary was produced through careful textual analyses, interpretation and mother-tongue theologizing that brings together Christian spirituality and the African (Bono) worldview. All Bono-Twi texts have been translated into English to make the work accessible to non-Akan readers as well. The main conclusions from the study are that (1) true believers must believe that Jesus is the Christ and he came in flesh (2) believers must (under no circumstance) compromise the basic truths about Christ and his salvation. Therefore, in a context where false teachers abound in various societies the church must stand for the truth, teach it and practicalize it to expose heresies.
\end{abstract}

Correspondence:

Isaac Boaheng

Email: revisaacboaheng@gmail.

com

\section{Manuscript}

Received 23rd August, 2021

Accepted 1st October, 2021,

Published online 19th October, 2021.

Keywords: False Teachings, Love, Second John, Truth

\section{INTRODUCTION: Background to 2 John}

The issue of the authorship of $2 \mathrm{John}$ is a complex one. The writer identifies himself as "the elder" (v. 1; 3 John 1) and shows his familiarity with and ecclesiastical authority over his audience 
through the use of both encouragement and dissuasion. ${ }^{1}$ The early church identified two Johns, the apostle and the elder. The common tradition in the early church tradition was however that the Apostle John authored this epistle. ${ }^{2}$ Johannine authorship of 2 John is affirmed by Apostolic Fathers (eg. Iranaeus and Clement) who wrote in the second century. ${ }^{3}$ Jerome's tradition (relatively a later one) however attributes 2 and 3 John to John the elder. ${ }^{4}$ Following Eusebius, many modern scholars have challenged the view that "the Johannine" epistles were written by John the Apostle. ${ }^{5}$ Most of their arguments are not based on "hard evidence" but on attempts to reconstruct the Johannine community. ${ }^{6}$ They argue that the title "the elder" is suggestive that the epistles were written by John the Elder. Contrary to this argument, Carson and Douglas say there is nothing wrong with an apostle referring to himself as an elder (1 Pet. 5:1). More so, the word "elder" may refer to an old person (cf. Philem. 9). John might have avoided the title "'apostle" to avoid sounding pompous." "Again, there are remarkable similarities between 1 John (which some scholars consider to have been written by John, the Apostle) and 2 John that stand against Jerome's view. ${ }^{9}$ Both letters address the same historical situation, namely, the presence of false teachers who reject Jesus' incarnation and "run ahead" to teach false doctrines about Christ (vv. 7, 9; cf. 1 John 2:19, 22-23). Both epistles label the false teachers as antichrists (v. 7; cf. 1 John 2:18, 22) and emphasize the importance of the command to love one another (vv. 4-6; cf. 3:11, 23; 4:7, 21; 5:1-4a). In each letter, the author expresses great joy in seeing his children following the truth (v. 4; cf. 1 John 1:34). Considering the debate surrounding the authorship of 2 John, the researcher acknowledges that no position on the authorship of 2 John is conclusive. This study will refer to the unknown author of 2 John as "the Elder" or simply "the writer."

The letter does not give the date of its writing. However, the situation it addresses leads to the conclusion that it was written around the time that 1 John was written. Based on this fact, Hodges considers the early AD 60s as the most probable date for writing 2 John. ${ }^{10}$ The letter is addressed to "the chosen lady (eklekte kyria) and her children" (v. 1 cf. vv. 4-5). Some common scholarly suggestions about the identity of the "chosen lady" include: a Babylonian lady named Electa, "the noble Kyria", "dear lady" (which is an expression for addressing an individual woman), an elect lady (referring to the entire church) and an elect lady symbolically referring to a particular church outside the author's society. ${ }^{11}$ Majority of New Testament scholars support the last position, that is, a particular church was personified as "chosen lady" and the congregation as "her children." 12

The letter addresses the same issues as 1 John but does so with brevity. False teachers influenced by Gnosticism were threatening the church (v. 7; cf. 1 John 2:18, 19, 22, 23; 4:1-3). ${ }^{13}$

\footnotetext{
${ }^{1}$ Colin G. Kruse, The Letters of John: The Pillar New Testament Commentary, edited by D. A. Carson (Grand Rapids, MI: William B. Eerdmans Publishing Company, 2000), 37.

${ }^{2}$ Zane C. Hodges, 2 John: The Bible Knowledge Commentary: New Testament edited by John F. Walvood and Roy B. Zuck (Colorado Springs: David C. Cook, 1983), 905.

${ }^{3}$ D. A. Carson and Douglas J. Moo, An Introduction to the New Testament (Nottingham: Apollos, 2005), 671.

${ }^{4}$ Kruse, The Letters of John, 36.

${ }^{5}$ Carson and Moo, An Introduction to the New Testament, 674.

${ }^{6}$ Carson and Moo, An Introduction to the New Testament, 675.

${ }^{7}$ Carson and. Moo, An Introduction to the New Testament, 674.

${ }^{8}$ Carson and Moo, An Introduction to the New Testament, 674.

${ }^{9}$ Kruse, The Letters of John, 36.

${ }^{10}$ Hodges, 2 John, 905.

${ }^{11}$ Kruse, The Letters of John, 37.

${ }^{12}$ Hodges, 2 John, 905.

${ }^{13}$ Kruse, The Letters of John, 39.
} 
First John, however, does not address a particular person or church, but 2 John was addressed to a particular local group or house-church (v. 1). John's second letter was meant to correct wrong teachings about Christ which some false teachers were propagating, to caution the church against deceivers, and to encourage believers to follow the truth, walk in love, and abide in the doctrine of Christ. ${ }^{14}$ The letter also serves as a forerunner to the writer's intended visit to the church (v. 12).

The attestation of 2 and $3 \mathrm{John}$ in patristic literature is somewhat weak due to the brevity of these epistles. Second John is the shortest book in the Bible and could have been contained on a single papyrus sheet. Yet, it has all the characteristics of a real letter as found in Greco-Roman Christian and non-Christian literature, namely, introduction of the writer and his audience (v. 1), greetings or blessings from the author (v. 3), acknowledgement of some report received (verse 4), author's request (vv. 5-11), an appropriate concluding formula (v. 12) and greetings (v. 13). ${ }^{15}$ Second John has similar thought and literary style as 1 and 3 John. Two major themes dominate this epistle-love and truth. For the sake of this study, 2 John is structured as follows:

I. Introductory greetings (vv. 1-3)

II. Commendation (v. 4)

III. III Exhortation and warning (vv. 5-11)

IV. Conclusion and final greetings (vv. 12-13)

The study now proceeds to offer a commentary on 2 John.

\begin{tabular}{|c|c|}
\hline Bono-Twi Text $^{16}$ & English Translation \\
\hline 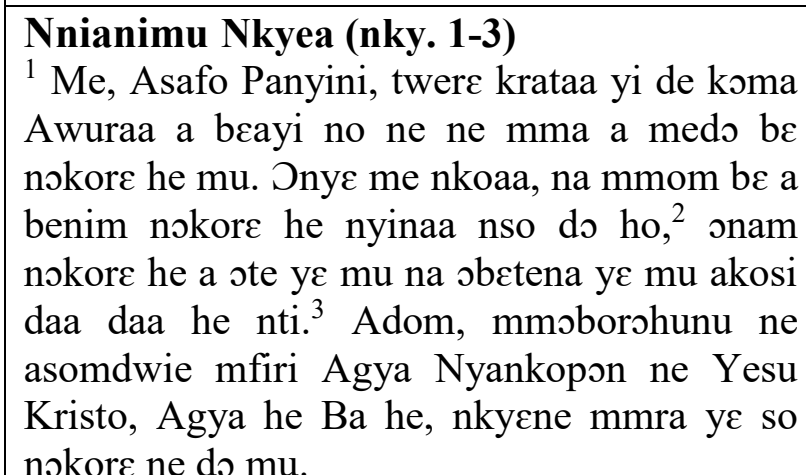 & $\begin{array}{l}\text { Introductory greetings (vv. 1-3) } \\
{ }^{1} \text { I, the church elder, write this letter to you the } \\
\text { elect lady and her children, whom I love in the } \\
\text { truth. I am not the only one who loves you, all } \\
\text { who know the truth also love you }{ }^{2} \text { because of the } \\
\text { truth which abides in us and will be with us } \\
\text { forever. }{ }^{3} \text { May grace, mercy, and peace from } \\
\text { God the Father and from Jesus Christ the } \\
\text { Father's Son come upon us, in truth and love. }\end{array}$ \\
\hline
\end{tabular}

${ }^{14}$ Kruse, The Letters of John, 39.

${ }^{15}$ Kruse, The Letters of John, 40.

${ }^{16}$ Bono is one of the largest ethnic groups of Akan. The Bono people live in parts of Ghana and Côte d'Ivoire. The word "Bono" means "first," "beginning," "pioneer" or the "first born on the land." Among the Akan, if a woman gives birth for the first time this is referred to as her "abonowo.." Similarly, when a couple begin the marriage life, they are said to "bono awaree." In the light of this, Bono people are normally tagged Akan piesie or Akandifos of which the name "Akan" is a derivative. Bono is the beginning and cradle of the Akan. The Twi language of the Akan derives its name from an ancient Techiman king, Nana Twi, whose language was tagged Twi's language. Bono-Twi is as ancient as other Twi dialects.

The Bono-Twi text (for 2 John) was translated from the original Greek version. The limited scope of the paper does not allow the inclusion of the Greek text in this paper, though from time to time there are references to transliterated Greek expressions. In translating the Bono-Twi text into English, there were cases where the researcher borrowed expressions from the NRSV. Again, where the researcher consulted an existing literature, the idea from the existing work was translated into Bono-Twi and referenced before translating the result into English. The Englsih version was thus not referenced and so one needs to get the reference for the English translation from the Bono-text text. 


\section{Nkyerskyeremu/Mpensempensemu}

Nkyekyemu mmeensa a odi kane he ye nwoma he mmieano. Twerefoo he da ne ho adi se "panyini" (a ogyina ho ma "Asafo panyini”"). "Panyini" (Griiki: ho prebiteros, "nipa a wanyini") ye abodini a na Yudafos ne Amanamane mufos nyinaa de ma nipa a bede anidie kesec ma no. Mmere bi duruic he, na asafo he nso de saa abodini yi ma asomafor de kyerc anidie a bede ma asomafoo he (kenkane 1 Pet. 5:1). Ne saa nti, megyedi paa se nipa a

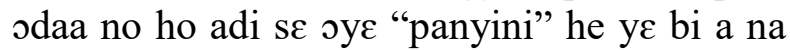
owo tumi asafo ahodoo mu anaa nipa a na odi mu paa asafo he nyinaa mu, te $\mathrm{s} \varepsilon$ somafor. ${ }^{17}$ Afei twerefoo he de Griiki asemfua "ho" ka asemfua "prebiteros" ho (ho prebiteros) de da no adi se na asafo mma bebree nim no ("panyini he").

Afei oda n'atiefoo he adi se "Awuraa a beayi no ne ne mma" (nky. 1). Abakosem a ofa nwoma yi ho di adanse $s \varepsilon$ "Awuraa a beayi no" he gyina ho ma asafo he (te se Yesaia 54 nso de baa gyina ho ma kuro Sion he). ${ }^{18} \mathrm{~S} \varepsilon$ bede kuro sototo baa ho he, na onnye ade foforo

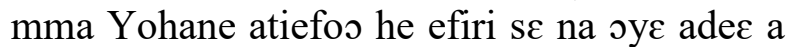
na abu so Tweresem he mu (te se "Sion babaa" ne Kristo ayefoyere, Efe. 5:22-23; 2 Kor. 11:2; Adiy. 19:7). Obeye dene paa se nsem "beayi no" ne "Awuraa" betumi aye nipa bi dini efiri s $\varepsilon$ saa Awuraa yi nuabaa nso ye "nea beayi no"

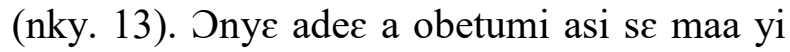
mmienu nyinaa de "nea beayi no." Afei nso, osane se "be a benim nokore he nyinaa nso do" baa yi a beayi no ne ne mma he nti, oda adi

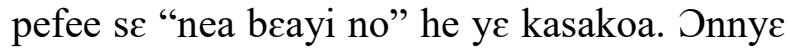
ade $\varepsilon$ a na asafo a sya wiase nyinaa betumi ahu baa bi ne ne mma (meekyere baa he ne n'abusua). Se kasakoa ne twerefoo he de oodi dwuma de $\varepsilon$ a, hedec "awuraa he mma" he gyina ho ma asafo mma he. Saa de $\varepsilon$ a na asem "beayi no" he kyere se Nyankopon ayi agyidifos afiri nnipa a beya asaase so nyinaa

\section{Commentary}

The first three verses form the opening part of the epistle. The writer identifies himself as "the elder" (which most likely means "the church elder"). "The elder" (ho presbyteros, lit. "the older-one") was an expression of respect that was used by both Jews and Gentile in reference to a respected person. Later, this term was adopted by the church to show respect to her apostles (see for example, 1 Pet. 5:1). Therefore, it is likely that "the elder" refers to one with authority over a group of local churches or an elder statesman of the church at large, an apostle. The definite article ho highlights the author's popularity in the church to which he wrote this letter.

The addressees are identified as "the chosen lady and her children" (v. 1). The background study favors the idea that the expression "the chosen lady" is a personification of a church (in a similar way that Isaiah 54 compares Zion to a woman). The personification of cities as female personage was not strange to John's audience because it was a common literary feature in biblical times (cf. "daughter of Zion" and "the bride of Christ" cf. Eph. 5:22-23; 2 Cor. 11:2; Rev. 19:7). The words "chosen" ("elect") and "lady" can hardly be proper names because the lady's sister is also "elect" (v. 13). It is unlikely that the two ladies have the name "the chosen lady." Also, the fact that the elect lady and her children are loved by "all who know the truth" supports a figurative use, for it is unlikely that a family (a woman and her children) had become so popular to be known universally by believers. If the figurative use is intended then "her children" refers to members of that local church. The word "elect" then highlights God's choice of believers from

${ }^{17}$ James B. De Young, 1-3 John: Baker Commentary on the Bible edited by Walter A. Elwell (Grand Rapids, MI: Baker Books, 2008), 1187.

${ }^{18}$ C. Haas, M. de Jonge and J.L. Swellengrebel, A Handbook on The Second Letter of John: UBS Handbook Series (New York: United Bible Societies, 1972), np. Electronic edition. 
mu se onam Yesu a oye Kristo he so bema be nkwa.

Afei twerefos he toa so ka se n'atiefos he ye nkurofos a "meds be nokore he mu (Griiki: $\varepsilon n$ aletcya)." Nwoma a Yohane twerce $\varepsilon$ he mu he, otumi de Griiki kasafua aleteya ("nokore") gyina ho ma Honhom Kronkron (kenkane Yoh. 14:17), Yesu Kristo ankasa (kenkane Yoh. 8:32; 14:6) anaa Assmpa he (1 Yoh. 3:23) nso. Nea ooka ne se be a benim nokore he nyinaa nso do n'atiefos

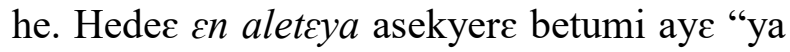
nokore he mu" na akyere se odo n'atiefoo he efiri $\mathrm{s} \varepsilon$ bebo be bra senea Yesu Kristo ho nokore he kyere heaa, senea twercfoo he nso yo he. Saa nso ne $\varepsilon n$ aleteya asekyere betumi aye

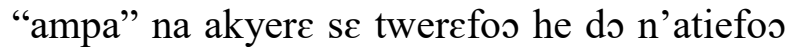
he paa ampa (nokorem). ${ }^{19}$ Me nsusuic ne se

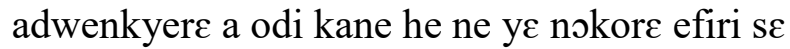
krataa yi mu asem titire ne se nipa behu nokor $\varepsilon$ he na ode abo ne bra.

"Asafo panyini" he da no adi ya nkyekyemu 2 he mu se one nnipa afofors binom do Awuraa a beayi no he efiri se nokore he te be mu na obetena be mu daa. Nti nokore a sya be mu he ye do a one binom do Awuraa

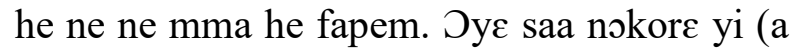

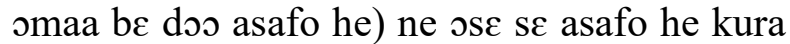
mu yie. ${ }^{20}$ Osane se Kristo ankasa ne Nokor $\varepsilon$ he (Yoh. 14:6) nti, obetumi aba se эye Kristo (a ste agyidifo mu ne one be betena daa) he ankasa ho asem ne krataa he ooka no ha yi. ${ }^{21}$ $\mathrm{S} \varepsilon$ ote saa a, hedec na kwane a bi fa so beka do abusua he ho nye se oogye Assmpa he ho nokore atom akoma mu nkoaa, na mmom os $\varepsilon$ se Kristo (a эує Ascmpa he nyinasoo he) nso tena gyidini biaa mu. ${ }^{22}$

Nkyekyemu 3 mu he, krataa twerefos he kyea n'atiefoo he na onam nkyea he so hyira be nso. Ode "adom, mmoborohunu ne asomdwie" mmra be so "nokore ne do mu." (Nkyea a nhyira ka ho te se nea yehu no ha yi among many people on earth to offer them salvation in Jesus, the Christ.

The writer proceeds to describe his audience as those "whom I love in the truth (en alètheia)." In Johannine writings alètheia ("truth") can refer to the Holy Spirit in John (cf. John 14:17), Jesus Christ himself (cf. John 8:32; 14:6) or the content of the Christian gospel (cf. 1 John 3:23). All who knew the truth of the gospel loved them as well. Here, en aletheia may be understood as "in the truth" to imply that John loves his audiences because they, like him, are living in accordance with the truth about Jesus Christ or "truly" to imply that the writer really loves his audience. The first option seems more plausible because of the letter's emphasis on knowing the truth and living by it.

"The church elder" reveals in verse 2 that he and others love the chosen lady because the truth lives in them and will be in them forever. Thus, truth is what attracted this love. This is the same truth that the church needs to guard. Since Christ is the embodiment of truth (John 14:6), it is possible that he is alluding to Christ "who abides" in believers and who will live with them "forever." To be part of the community of love requires one not only to internalize the truth of the gospel, but also to experience the indwelling of Christ (embodiment of the gospel message).

In verse 3 , the writer blesses his audience in the form of greetings, saying "grace, mercy and peace" will be their portion "in truth and love." (For similar blessings see Rom. 1:7; 1 Cor. 1:3; 2 Cor. 1:2; Gal. 1:3; Eph. 1:2; Phil. 1:2;

\footnotetext{
${ }^{19}$ Kruse, The Letters of John, 205.

${ }^{20}$ Hodges, 2 John, 906.

${ }^{21}$ Kruse, The Letters of John, 205.

${ }^{22}$ Kruse, The Letters of John, 205.
} 
nso bi ya Rom. 1:7; 1 Kor. 1:3; 2 Kor. 1:2; Gal. 1:3; Efe. 1:2; Fil. 1:2; Kol. 1:2; 1 Tes. 1:1; 2 Tes. $1: 2 ; 1$ Tim. 1:2; 2 Tim. 1:2; Tit. 1:4; Fel. 3; 1 Pet. 1:2; 2 Pet. 1:2; Yuda 2; Adiy. 1:4). Nso nsonsonoee da kwane a twercfor he fa so kyea na ohyira n'atiefos he ne kwane Apam fofors atwercfos binom nso yo saa he ntam. Nea twercfor he ka he ye nhyira anakasa na oohyira n'atiefoo he na mmom onnye se ooka biibi a oda n'akoma so keke. Twercfoo he ka a oka se "...mmra ye so" (Griiki: estai met hemon) ya saa nkyekyemu yi ahycasec ya Griiki kasa mu he ne oma meka saa. ${ }^{23}$

Kasafua (Griiki: kyaris) kyere adom bi a nipa bi anya a nka ofata $s \varepsilon$ onya; saa kasafua yi kae agyidifo se Nyame adom nti ne bewo nkwa. ${ }^{24}$ Kasafua "mmoborohunu" (Griiki: cless) nso kyere Nyankopon tema a ow ma agyidifo ber $\varepsilon$ biaa, nim a onim be ahiadec, one krado a waye $\mathrm{s} \varepsilon$ obema be be asetena mu ahiade $\varepsilon$ nyinaa. ${ }^{25}$ Griiki asemfua "cless" ne

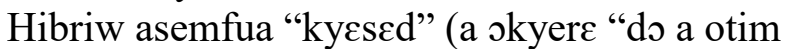
ho daa") nyinaa kyere adekoro heaa; se yede asemfua "kyesed" di nkwagye $\varepsilon$ ho nkomm a a, ogyina ho ma Nyankopon su a smaa no de bone ho asotwe too nkyene na ogyee nnipa nkwa firi be bone mu. ${ }^{26}$ Adom ne mmoborohunu ye Nyankopon su mmienu a skabom di dwuma ma asomdwie ba Nyankopon ne nnipa ntam. "Asomdwie" (Griiki:cirene) ba berc debonyeni bi asakra n'adwene, na saa nti Nyankopon atwe bone ho asotwe asensene. Griiki dini-asem cirene (ya saa ascm yi mu he) gyina ho ma Hebriw kasafua "hyalom" (a okyere "nkwahosane"). ${ }^{27}$

Nkamfoo (nky. 4)

${ }^{4}$ M'ani gyee kese se mehuu se wo mma he bi nam nokore he mu senea Agya he ahye ye heaa.
Col. 1:2; 1 Thess. 1:1; 2 Thess. 1:2; 1 Tim. 1:2; 2 Tim. 1:2; Tit. 1:4; Phlm. 3; 1 Pet. 1:2; 2 Pet. 1:2; Jude 2; Rev. 1:4). The writer's formula differs from those of other New Testament writers in that his blessing is more of an affirmation than a wish as indicative by his use of the expression "...will be with us" (estai meth' hèmōn) at the beginning of the Greek sentence.

Here, "grace" (charis) denotes an unmerited favor and reminds believers of the way they were saved while "mercy" (eleos) underlines God's unfailing concern for believers, his consciousness of their needs and his readiness to provide for them. The word "eleos" translates the Hebrew term chesed ("steadfast love") and in soteriological terms, sets aside the penalty that God's justice prescribes for human sins. Grace and mercy work together to make peace between God and humans. "Peace" (eirénē) may come as a result of God relieving the repentant sinner of the penalty of sin. The Greek noun eirếne in this context corresponds to the Hebrew shalom ("well-being"). ${ }^{28}$

\section{Commendation (v. 4)}

${ }^{4}$ I rejoiced greatly to find some of your children walking in the truth, just the Father has commanded us.

\footnotetext{
${ }^{23}$ Kruse, The Letters of John, 205.

${ }^{24}$ Haas, Jonge and Swellengrebel, The Second Letter of John, n.p.

${ }^{25}$ Haas, Jonge and Swellengrebel, The Second Letter of John, n.p.

${ }^{26}$ Haas, Jonge and Swellengrebel, The Second Letter of John, n.p.

${ }^{27}$ Haas, Jonge and Swellengrebel, The Second Letter of John, n.p.

${ }^{28}$ Haas, Jonge and Swellengrebel, The Second Letter of John, n.p.
} 


\section{Nkyer\&kyerєmu/Mpensempensemu}

Krataa twercfoo he "ani gyee kese" se ohyiaa Awuraa he mma he binom na ohuu se bebo be bra senea nokore he ka he pepecpe (nky. 4). Adeyo-ascm "maahu" anaa "menim" (Griiki: hcureka) asekyerc ne "maate", "mede m'ani abu se," "maahyia." 29 Asafo panyini he ani nnye se ne nkurofoo he benya nokore he nimde $\varepsilon$ nkoaa $k \varepsilon k \varepsilon$, na mmom n'ani gye $s \varepsilon$ bebenya ho nimdee na beanante mu nso.

Kasafa "nam mu" (Griiki: peripatuuntas) ye kasakoa a twerefoo he de gyina ho kyere se nipa bi de asem bi (anaa adesua bi) osbo ne bra da biaa; saa nti asemsini "nam nokore he mu" kyere se bi sobo ne bra scnea nokwasem a ofa Kristo Ascmpa he tee

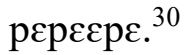

$\mathrm{S} \varepsilon$ twerefoo he ka se "scnea Agya he ahy $\varepsilon$ y heaa" a, na nnooma a odidi so yi mu bi

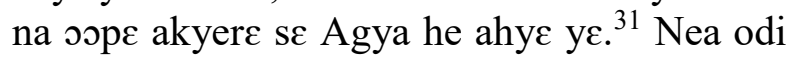
kane, obetumi aba se Agya he ahyedec a ooka ho assm he ne se nnipa nyinaa betie ne Ba he (Mar. 9:7; Matt. 17:5). Afei nso, ebia na "Agya he ahyedee" he gyina ho ma hu a bi behu na wagye atom $s \varepsilon$ Yesu nkyerckyere nyinaa ye nea Agya he ahye, na ne saa nti Yesu nsem nso ye Agya he ahyedec (Yoh. 12:50). Oto so mmeensa he, obetumi aba se Asafo panyini he de "Agya he ahyedee" gyina ho ma Ascmpa a Akristofor bo ho dawuro he. $\mathrm{S} \varepsilon$ wode nkyekyemu 4 yi toto 1 Yohane 3:23 ho a, oda adi pefee $s \varepsilon$ adwenkyer $\varepsilon$ a oto so mmeensa he

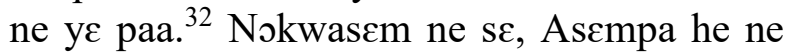

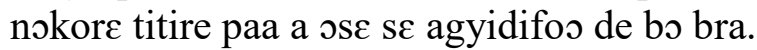

\section{Afutuo ne koksbo (nky. 5-11)}

${ }^{5} \mathrm{Nti}$ afei, Awuraa, mesre wo, yennodo ye ho

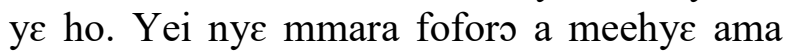
wo, na mmom oye mmara a yenya firii mfitiase $\varepsilon$ heaa. ${ }^{6} \mathrm{Na}$ do a meeka ho asem yi di:

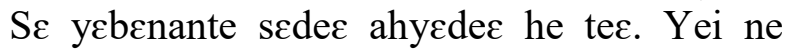

\section{Commentary}

The writer "rejoiced greatly" because he met some of his children and found that they were living according to the truth (v. 4). The verb "to find" or "to know" (heurēka) means "to hear," "to perceive," "to meet." "The elder" is not just happy because his people know the truth but that they walk in it too.

The expression "walking in" (peripatountas) is used figuratively to denote how one conducts his/her daily life; therefore, the expression "walking the truth" means living loyally and faithfully to the truth of the message of the gospel of Christ.

The expression "just as we have been commanded by the Father" presents three possibilities regarding what the Father's command is ${ }^{33}$ First, it may be an allusion to the Father's command that humans listen to his Son (Mark 9:7; Matt. 17:5). Second, it may refer to the recognition that Jesus' teachings are the Father's commands (John 12:50). Third, it may be that "the elder" is here equating the Christian gospel to the Father's command. The third option is the most probable when the text is read in the light of 1 John 3:23. The gospel message is the main truth which believers are commanded to follow.

\section{Exhortation and warning (vv. 5-11)}

${ }^{5}$ And now I beg you, lady, that we love one another. I am not giving you a new commandment, but the one we have had from the beginning. ${ }^{6}$ And this is the love I am writing to you about: that we follow his commandments;

\footnotetext{
${ }^{29}$ Haas, Jonge and Swellengrebel, The Second Letter of John, n.p.

${ }^{30}$ Kruse, The Letters of John, 207.

${ }^{31}$ Kruse, The Letters of John, 207.

${ }^{32}$ Kruse, The Letters of John, 207.

${ }^{33}$ Kruse, The Letters of John, 207.
} 
ahycde $\varepsilon$ a hote firii mfitiase $\varepsilon$ he $s \varepsilon$, honnante

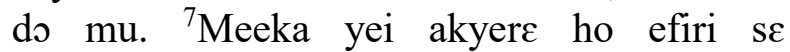
nnaadaafoo bebree aba wiase a bempae mu nka se Yesu Kristo baa honam mu. Nipa a ste saa he ne daadaafoo he ne nea oko tia Kristo he. ${ }^{8}$ Honhwe ho ho so yie na hoanhwere nea hoays ho adwuma, na mmom hoanya ho akatua nyinaa. ${ }^{9}$ Nipa biaa a omane firi kwanpa he so na ontena Kristo nkyerckyere he mu he, onnim Nyankopon. Na nea stena nkyerekyerc he mu he, sno mmom ne nea onim Agya he ne ne Ba he. ${ }^{10} \mathrm{~S} \varepsilon$ bi ba ho nkyene na onnye saa nkyerckyere yi na ode nam a, honnnye no nko ho fie, na honnkyea no nka se, "Asomdwie nka wo," ${ }^{11}$ efiri se, biaa a ode Nyankopon asomdwie bema no he nso de ne ho forefore saa nipa he nnebone he mu.

\section{Nkyerekyer\&mu/Mpensempensemu}

Nkyekyemu 5 he mu he twercfor he kyere n'atiefoo he kwane a bebefa so atena nokore he mu. Osre se one Awura a beayi no he nko so nnodo be ho be ho. Kwane a twerefor he faa so de adeyo-asem "do" dii dwuma he da no adi se

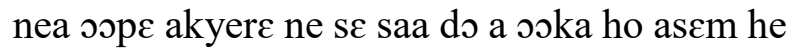
gu so osda ne ho adi agyidifoo nyinaa mu. ${ }^{34}$ Saa ahyedee yi nye ade foforo koraa, oye ahyedee a twercfoo he ne n'atiefor he nim firi mfitiase (Griiki: ap arkyes). Yesu de ahyedec titire a ofa do ho maaec bere a na oya asaase so oodi dwuma he (Yoh. 13:34-35). Nea twerefoo

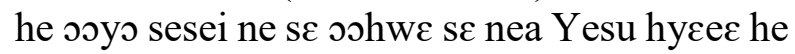
beba mu asafo he dwumadie mu. Adesua a sya mu ne s $\varepsilon$ gyidini abrabo ho nkontabuo gyina do a odo afoforo so (1 Yoh. 4:20-21).

Nkyekyemu 6a kyere se gyidini a owo do he ne nea odi Yesu ahyedec so. Yei kae ye

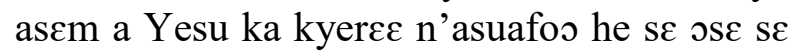
$\mathrm{b} \varepsilon$ do a bew n'ahyedec so (Yoh. 14:15, kenkane 1 Yoh. 5:23a nso). Nipa a onnyo setie mma Nyankopon he nni gyidie anaa do mapa. Gyidini a oshwehwe Nyankoon nnepa ama ne yonko he, os $\varepsilon$ se ohwehwe no Nyamesuro kwane so. ${ }^{35}$ this is the commandment, as you have heard from the beginning, that you follow love. ${ }^{7}$ I say this to you because many deceivers have gone out into the world, people who do not acknowledge the coming of Jesus Christ in the flesh; such a person is the deceiver and the antichrist. ${ }^{8}$ Watch out that you do not lose what you have worked for, but may have a full reward. ${ }^{9}$ Any one who goes astray and does not abide in the doctrine of Christ does not know God; he who abides in the doctrine knows both the Father and the Son. ${ }^{10}$ If any one comes to you and does not bring this doctrine, do not receive him into the house or greet them "peace be with you" 11 because he who greets him shares his wicked work.

\section{Commentary}

In verse 5, the writer demonstrates to his audience how they should live in the truth. He asks that he and the "elect lady" (the church) will continue in their mutual love for one another. The use of the present subjunctive form of the verb "to love" is indicative that the writer is talking about an ongoing love of fellow believers. This commandment is not new but something the writer and his audience had known from the beginning (ap' archēs). Jesus gave the great commandment of love during his earthly ministry (John 13:34-35). The writer is now ensuring that what Jesus commanded comes to pass in the church. The quality of the believer's life is measured by our love for one another (1 John 4:20-21).

The first part of verse 6 defines a believer's love in terms of following Jesus' commandment. This reminisces Jesus' statement to his disciples that their love for him must lead to willful obedience to his commands (John 14:15, see also 1 John 5:2-3a). One who does not obey God does not have real faith or true love. A believer who seeks God's best for someone should only do so in the fear of God

\footnotetext{
${ }^{34}$ Kruse, The Letters of John, 208.

${ }^{35}$ Hodges, 2 John, 906-907.
} 
Nee ote $\varepsilon$ ne $s \varepsilon$, gyidini biaa a onante nokore he mu (nky. 4) do afoforo; nti, se bi osdo bi, one se ээу⿰ setie ama no he, ye adekoro.

Nnooma mmienu bi ya nkyekyemu $6 b$ mu a ohia nkyerckyeremu kakra. ${ }^{36}$ Nea odi kane koraa ne se, nea asemfua haute ("yei")

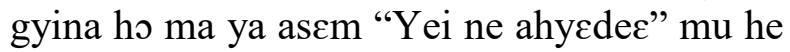
nna adi papa. Obetumi aba se "yei" gyina ho ma biibi a sya nkyekyemu 6a (a "ono nso kyerckyere nkyekyemu 5 he awiees he mu") anaa asemfua "yei" ooka biibi afa "s $\varepsilon$, honnante do mu" a sya $6 \mathrm{~b}$ he ho. ${ }^{37}$ Twer Kronkron atwercfos bebree (a be a betwerce RSV Twerc Kronkron he ka ho) fa no se "yei" gyina ho se ookyerckyere "mu ne ho nante"

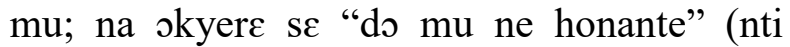
"honante do mu"). ${ }^{38}$

Nea sto so mmienu ne $s \varepsilon$, ya Griiki asemsini hina $\varepsilon n$ aute periaptete (sc wofa no traa a okyere se "na honni so") mu he, bi ntumi nhu adekoro potee a twercfoo he oska se benni

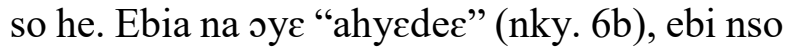
a na atwerefos dodos he (a be a betweres RSV ne NIV Twere Kronkron he ka ho) fa no se adekoro a $\mathrm{s} \varepsilon$ dinsiananmu aute ye dinsianamu a bedegyina ho ma dini a owo mmaa su, ne saa nti obetumi asi dini ascm agape ("do" a ono so te saa he) anaamu; na afei nso, ade potee a twercfoo he ka ho ascm nkyekyemu 5-6 mu he $\mathrm{y} \varepsilon$ do a agyidifo benya amema be ho be ho nti,

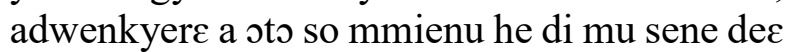
odi kane he.

Twercfos he de asemfua hoti ("na"

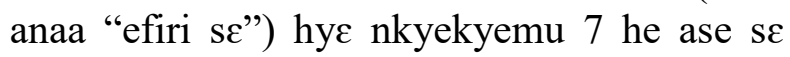
onka nkyekyemu 7 he ne nkyekyemu 6 he mmom; yei nso sane boa ma atiefos he hu hia ohia se bebenante nokore he mu. ${ }^{39}$ Twersfoo he da no adi $s \varepsilon$ toro akyerckyerefos bebree (meekyere "nnadaafoo," Griiki: planıi, "nnipa a bema bi mane firi kwane pa so" kenkane 1 and in accordance with obedience to his will. Believers who live in the truth (v. 4) love one another; to love is to obey.

Verse $6 \mathrm{~b}$ is ambiguous in two aspects. First of all, what the demonstrative haute ("this") in the expression "this is the commandment" refers to is not clear. The possibilities are that it points back to verse 6 a ("which in its turn explains the last clause of verse 5") or forward to the "that clause" (that is, "that you follow love") of verse 6b. Majority of translations (including the RSV) consider "this" as referring to something forward; this position interprets the expression "in it you walk" as meaning "in love you walk;" hence, "you follow love."'

Secondly, in the expression hina en autē peripatète (lit. "that you follow it"), the antecedent of the pronoun "it" is difficult to determine. "It" may refer to "commandment" (v. 6b) or to "love" (v. 6a). Majority of translations (including the RSV and NIV) interpret follow "it" to mean follow "love." The facts that the pronoun autē ('it') is a feminine pronoun and could therefore have agape ("love"), a feminine noun, as its antecedent and that the main concern of verses 5-6 is mutual love, make this position more likely.

The writer begins verse 7 with the particle hoti ("for" or "because") to link the previous verse with this one and to help his addressees to appreciate why he considers it so important for them to follow the truth. The writer indicates that many false teachers (or deceivers, Greek: planoi, "ones who lead astray"; cf. 1 John $2: 18 ; 4: 1$ ) went from place to

\footnotetext{
${ }^{36}$ Haas, Jonge and Swellengrebel, The Second Letter of John, n.p.

${ }^{37}$ Haas, Jonge and Swellengrebel, The Second Letter of John, n.p.

${ }^{38}$ Haas, Jonge and Swellengrebel, The Second Letter of John, n.p.

${ }^{39}$ Hodges, 2 John, 907.
} 
Yoh. 2:18; 4:1) nante mmeammea

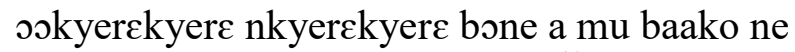
$\mathrm{s} \varepsilon$ Yesu amma honam tebea mu. ${ }^{40}$ Ohia paa $\mathrm{s} \varepsilon$ agyidifo bo be bra senea Nyankopon ahyedec te $\varepsilon$ efiri $\mathrm{s} \varepsilon$ "nnaadaafor bebree aba wiase." Nnaadaafos he ne be a bennye ntom $s \varepsilon$ Nyankopon Ba he befaa honam tebea kaa ne Nyame su he ho. $\mathrm{B} \varepsilon$ mu binom nso kyerckyerec se Yesu amma honam mu ankasa, na mmom na ose bi a na sya honam mu; be nkyerckyere ne se, woko mu paa dec a na onni honam mu ankasa. Se bi annye antom $\mathrm{s} \varepsilon$ Yesu baa $s \varepsilon$ nipa trodoo a, saa nipa he ye daadafos ne nea oko tia Kristo he nso (1 Yoh. 2:18). Nea

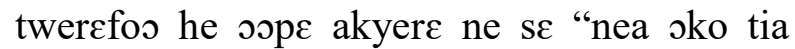
Kristo he" nye bi a daakye bi obeba nkoaa, na

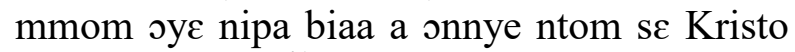
aba honam mu. ${ }^{41}$ Saa dec a, na "nea oko tia Kristo he" nye adefoforo koraa mma nneemafos efiri se berc biaa mu he yews saa nnipa he bi ya wiase. Twerefor he bo n'atiefos he koko fa saa nnipa a beko tia Kristo he ho nso ya 1 Yohane $(2: 18-23,4: 3)$. Ne nyinaa mu he, bere bi nso soba nna a odi akyire he mu a "nea oko tia Kristo he" beda ne ho adi se nipa a obedi nnipa bebree anim ama beate Nyankopon so atua.

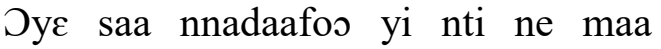
twerefoo he boว n'atiefo he kokっ se benhwe yie na be ne nnadaafos yi nkitahodie he amma be annye be (nnadaafos he) nkyerckyerc bone he na beanya (meekyere $s \varepsilon$, n'atiefos he anya) honhom mu haw biaa (nky. 8). "Se bi oshwe no ho so yie" kyere se osbo ne ho bane afiri atoro nkyerckyere ne ho nsunsuansos ho.

Nkyekyemu 9 he mu he, twercfoo he ka biibi fa be a mmere bi a atwam he na benim nokore he na afei dec beafiri ho. Twercfoo he tu n'atiefoo he fo $s \varepsilon$, onse $s \varepsilon$ bi yo biibi tra Kristo nkyerckyere he (anaa bi mane firi kwanpa he so na ontena Kristo nkyerckyere he

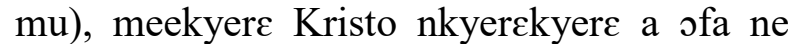
"nipabane" ne ne dwumadie ho. Se twercfoo he ka se "Biaa a omane (Griiki: proagon) firi place to preach false doctrines, one of which was that Jesus did not come in the flesh. It is very important that believers walk according to the old known biblical commandment because "many deceivers have gone out into the world." The deceivers (in this context) are those who do not subscribe to the incarnation of the Son. Some of them taught that Jesus only appeared to be human; he was in reality not human. The denial of Jesus' true humanity marks a person not only as a deceiver but also as an antichrist (cf. 1 John 2:18). The antichrist, according to this verse, is not a particular eschatological figure but anyone who does not accept that Christ has come in the flesh. The antichrist is therefore not a new concept; he has been in the world since the time of the early church. The author warns his audience against these antichrists in his first letter $(2: 18-23,4: 3)$. However, there will be an end-time Antichrist who will lead humanity in a rebellion against God.

The presence of these deceivers makes the writer warn his audience to be watchful in order to avoid the disastrous spiritual effects that one's encounter and acceptance of false teachings can bring (v. 8). "To watch out" requires protecting oneself from the influence of false teachings.

In verse 9, the writer focuses on those who once held to the truth and are now defecting. The verse admonishes readers never to go "beyond" the teaching of Christ, of his personality and his works. The expression "Anyone who goes ahead (proagōn) and does not abide in the doctrine of Christ" refers to those who receive the truth, live by it but later allow themselves to be deceived by the false

\footnotetext{
${ }^{40}$ Hodges, 2 John, 907.

${ }^{41}$ Hodges, 2 John, 907.
} 
kwanpa he so na ontena Kristo nkyerckyere he mu" a na okyere be a beagye nokore he atom, de adi dwuma na afei dec beama be ho kwane ama nnadaafos adaadaa $b \varepsilon^{42}$ Nnipa a bete saa he nni Kristo nkyerckyerc so, saa nti "bennim Nyankopon." Yei ye nokwasem paa efiri $s \varepsilon$ onam Kristo so ne nnipa hu Nyankopon (Yoh. 14:6), saa nti se bi nnye Kristo nni a, onntumi mma Nyankopon nkyene. Biaa nni ho a obetumi ahu Agya he bere a onni kane nhu ne Ba he (Yoh. 14:9). Toro nkyerckyere de nnipa

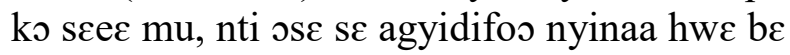
ho yie saa nnipa he ho.

Twerefoo he toa so ka $s \varepsilon, s \varepsilon$ bi pe se otoa so tena Kristo ho nokore he mu a, ose se saa nipa he gyina pintinn tia toro nkyerckyere (nky. 10-11). Se oka $\mathrm{s} \varepsilon$ "S $\mathrm{S}$ bi ba ho nkyene na

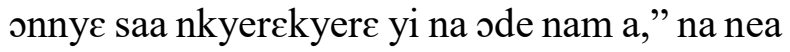

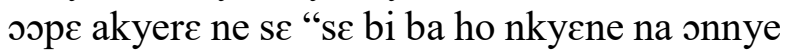
nkyerckyere papa ofa Kristo ho he ntom, na

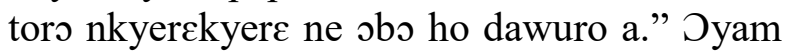
$\mathrm{s} \varepsilon$, os $\mathrm{s} \varepsilon$ atiefoo he gye ahohoo ba be asore ne be fie mu dee, nso onse $\mathrm{s} \varepsilon$ begye toro akyerckyercfo efiri $\mathrm{s} \varepsilon, \quad \mathrm{s} \varepsilon$ begye saa akyerckyercfo yi a be tor nsem he betumi ama asafo mma yi amane afiri kwane pa he so. ${ }^{43}$ Twercfoo he ka kyere n'atiefos he $s \varepsilon$ bennkyea tor akyerckyercfoo he mpo efiri $s \varepsilon$ anhwe a na nipa a ogyina nkyene he akodwene $\mathrm{s} \varepsilon$ befoa be nkyerekyere bone he so. Nkyea (Griiki: kyaircin) a twercfos he soka ho ascm y $\varepsilon$ Griikifo nkyea a ono ne se "ma wo ani nnye oo!" (Griiki: kyairo). Saa nkyea yi kyere se bi osma ne yonko akwaaba anaa nante yie scnea bi tumi ka se: "M'ani agye se maahu wo!" anaa "Onsi wo yie!" (kenkane Aso. 15:23; 23:26;

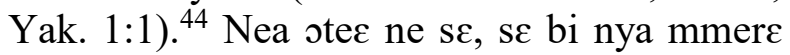
ma saa akyerckyerefoo he a na soboa be ama be toro nkyerckyere he atu mpono; saa nipa he nso foa be nnwuma bone he so. teachers. Such people do not obey what Christ said and so do "not have God." This conclusion is logical in that it is through Christ that people come to God (John 14:6) and so without belief in Christ one cannot go to God. No one can know the Father without first of all knowing the Son (cf. John 14:9). The end of false teachings is destruction and so believers must guard against them.

The writer then proceeds to make the point that "continuing" in the truth about Christ requires a firm response against false teachers (vv. 10-11). The statement "If anyone comes to you and does not bring this doctrine" means if someone comes denying the true doctrine of Christ, and promoting a false doctrine of Christ. While the readers are expected to welcome strangers to their church and homes, they must not welcome false teachers. Such teachers, when entertained, will teach false doctrine and lead them astray. The writer commands them not to welcome false teachers because giving one of the opponents' representatives a greeting in public could be construed by bystanders or observers as endorsing their false doctrines about Christ. The greetings (chairein) that the writer has in mind here relates to the Greek verb "to rejoice, be glad" (chaírō) and signifies a cordial address of welcome or farewell such as "I am glad to see you" or "I wish you well" (cf. Acts 15:23; 23:26; James 1:1). At the same time, giving support to false teachers in a way will promote their own false version of Christ. To do so is to share in their evil deeds.

\footnotetext{
${ }^{42}$ Hodges, 2 John, 908.

${ }^{43}$ Samuel Ngewa, 2 John: African Bible Commentary edited by Tokumboh Adeyemo (Nairobi: WolrdAlive, 2006), 1563.

${ }^{44}$ Hodges, 2 John, 908.
} 
Nea twercfos he soka no nkyekyemu 10 he mu he, se wode toto Abibifoo ahohoye su, Kristo ahyedee se agyidifo nyi do adi nkyere be atamfos (Mat. 5:44), ne Paulo nkyerckyere se agyidifos nys ahohos yie (Rom. 12:13; 1 Tim. 3:2; 5:3-10; Tit. 1:8; Heb. $13: 2$; Pet. $4: 8-10$ ) he ho a, na ohia $s \varepsilon$ yenya nkyerckyercmu kakra. Nokwasem ne $s \varepsilon$, nea

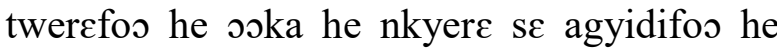
ntane tors akyerckyercfos he. Daabi, boa mmom ne soboa n'atiefos he ama beatwe be ho afiri nsunsuanso bone a nkyerckyere bone betumi de abra be (na onam so ama beapa be gyidie) he ho. Dotwe n'atiefor he adwene asi biibi so $s \varepsilon$, nkyerckyerc bone te $s \varepsilon$ nsane-yadec, otumi sane nipa biaa. ${ }^{45}$ Nea twerefoo he oska he da adi Nkranfoo be a bebu no se "ke osi nme le, eko ya emama mli" ("wontumi nwo abe ber $\varepsilon$ a bi nkeka wo ataadec/ntoma mu") he mu.

$\mathrm{S} \varepsilon$ ste saa dec, na nea twercfos he soka he fapem ne do a ows ma n'atiefos ne bo a wabo ne tim po se obcko atia nkyerckyerc bone kosi $\mathrm{s} \varepsilon$ tor adwene he. Nea otec ne $s \varepsilon, s \varepsilon$ bi gye toro

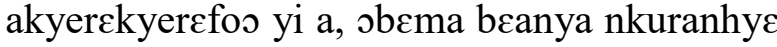
na be adwene ayo be se saa nipa he foa nea becyo he so; yie nso bema be nnebone he so akata koraa. Yei nkyere se gyidini ntane tors

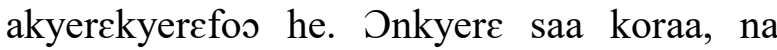
mmom, okyere $\mathrm{s} \varepsilon$ onse $\mathrm{s} \varepsilon$ gyidini boa ma

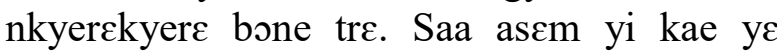
kokıbo a Yesu bo n'asuafoo he se "Honhwe yie atoro adiyifos ho, bene befira dwane nwoma ba ho nkyene nso be mu paa dec beye mpataku" (Mat. 7:15). Nokwasem ne se, onse $\mathrm{s} \varepsilon$ gyidini bi ne toro akyerckyercfoo he tena te $\mathrm{s} \varepsilon$ one gyidini tena. Osane $\mathrm{s} \varepsilon$ beyc atorofoo, na bennye Nyankopon Ba he nni nti, se bi gye be tom a obeye te $s \varepsilon$ saa nipa he oodi Nyankopon ho few; saa nipa he yo bone tia Nyankopon. ${ }^{46}$ $\mathrm{Nti}$, nea twercfos he soka he botae ne $\mathrm{s} \varepsilon$, obeboa ama asafo he ako so aye korogyee na
The question of how the writer's statement in verse 10 should be understood in the light of African hospitality, Christ's statement that believers should love their enemies (Matt. 5:44) and the biblical command to show hospitality (Rom. 12:13; 1 Tim. 3:2; 5:3-10; Tit. 1:8; Heb. 13:2; Pet. 4:8-10), needs attention at this point. What the writer is saying does not mean the believers should hate false teachers. Rather, he is helping his readers to avoid the possibility of being negativity influenced by the false teachers and hence forsaking their true belief. $\mathrm{He}$ is drawing attention to the contagious nature of false teachings. This idea agrees well with the $\mathrm{Ga}$ proverb which says, $k \varepsilon$ oshi nme le, eko yaa omama mli ("If you pound palm nuts, some will stain your cloth").

The writer's directive is rather an act of love in that clearly demonstrating an intolerance for false teachings would signal false teachers that their teachings are unacceptable and so they needed to repent. Similarly, extending hospitality to false teachers would be a sought of encouragement for their position and they (the false teachers) would then take this action as an acceptance of their teachings or as a covering of their unrighteousness. It does not mean people should hate those involved in such pernicious ministries; rather, it means people should not help such ungodly ministries to survive. The writer's directive echoes Jesus' warning to his disciples to beware of false prophets "Beware of false prophets, who come to you in sheep's clothing but inwardly are ravenous wolves" (Matt. 7:15 NRSV). The fact is that because the false teachers do not accept the Son, accepting them as fellow workers of God will amount to mocking God and sinning against him. The writer is therefore encouraging the local church to remain pure and devoted to Christ. The Ga

\footnotetext{
${ }^{45}$ Samuel Ngewa, 2 John: African Bible Commentary edited by Tokumboh Adeyemo (Nairobi: WolrdAlive, 2006), 1563.

${ }^{46}$ Glenn W. Barker, 2 John: The Expositor's Bible Commentary, vol. 12 edited by Frank E. Gaebelein (Grand Rapids, MI: Zondervan, 1981), 365.
} 
asafo he atu ne ho asi ho ama Kristo nkoaa. Nkranfoo be "nine se ke koto ten yee he gbo" ("nsaakyi ne nsayam nni nkabom biaa") ne Bonofor be "sum ne hann nni twaka biaa" si asem yi so dua paa. Senea bi ntumi nsom Nyankopon ne Ahonyadee mmom bere kors heaa mu he (Mat. 6:24), saa nso ne bi ntumi ne Nyankopon ne bonefos he mfa ayonkos berc kors heaa mu nso (1 Kor. 10:20). Yei nso nkyere se gyidini ntumi ne wiaseni nni nkomms anaa mfa adamfos. Agyidifos ne wiasefor betumi afa adamfor adi nkommo a ne botae ne se wiaseni he benya adwensakra. Mmom hye no nso $s \varepsilon$, nnipa a be gyidie atim yie a bi ntumi ntwe be mfiri gyidie he ho nkoaa

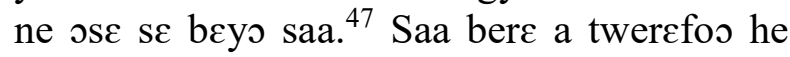

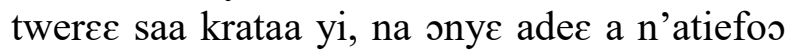
he anyini gyidie he mu papa; nti na osuro $s \varepsilon$ anhwe a na toro akyerckyerefos he atwe n'atiefoo he afiri gyidie ne nokore he ho. ${ }^{48}$

$\mathrm{Y} \varepsilon$ daadaa asetena mu he, awofos tumi kyere nipa a Yei hia paa ofiri se abofra nnim adamfos anaa nipa a obetumi anya nsunsuansos bone ya n'abrabo so. $\mathrm{S} \varepsilon$ awofo y yei na $\mathrm{s} \varepsilon$ be mma he nyini wei a, begyaa be ma be ankasa bekyerc nipa a bene no besane anaa bene no onsane. Awofoo he hye a behyec be mma he se bemfa asomasi anaa bentene adamfoo he nkyere se na betane saa nipa he anaa be mma he; na mmom

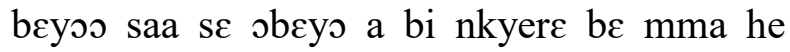
akyerebone. Saa ne nkyekyemu a yecpensempensemu yi nso tee. Onye tane ne twercfos he tane tors akyerckyerefos he, na mmom ope se obo n'atiefos he ho bane firi nkyerckyere bone ho na asafo a afei ne oonyini he ansee. ${ }^{49}$

Awieec ne nkyea a otwa too (nky. 12-13)

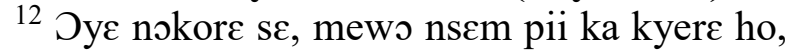
nso memfa krataa ne tweredua so nka; na proverb nine sec ke koks ten yee he gbo ("The back of the hand and the palm do not unite") or the Akan proverb sum ne hann nni twaka biara ("Light and darkness have nothing in common") aptly captures this thought. ${ }^{50}$ Just as one cannot serve both God and Mammon simultaneously (Matt. 6:24) so can no one be a partner of God and of the devil at the same time (1 Cor. 10:20). This verse does not mean believers should have nothing to do with unbelievers. Believers can invite these people for a conversation geared toward conversion. However, only mature believers with resilient faith whose understanding is beyond corruption may do so. The writer's addressees were not mature enough at the time the letter was written and he feared their faith might be destroyed by the false teachers. $^{51}$

In everyday life, parents discriminate as to whom (even among their own family members) a child should associate with. This is important to ensure that the life of the child is not ruined by bad influence. When the child grows, he/she may associate with everyone without necessarily having his/her life ruined. The restriction on who a child can associate with and who he/she cannot associate with is not done out of hatred but as a measure to ensure that the child is protected against bad influences. Similarly, the writer does not in any way hate the false teachers, but simply wants to prevent his readers from their heresy that has the potential of destroying the young church.

Conclusion and Final Greetings (vv. 12-13)

12 Though I have much to write to you, I would however not use paper and ink; but I hope to

\footnotetext{
${ }^{47}$ Barker, 2 John, 366.

${ }^{48}$ Barker, 2 John, 366.

${ }^{49}$ Barker, 2 John, 366.

50 Ngewa, 2 John, 1563.

${ }^{51}$ Barker, 2 John, 366.
} 
mmom, mewo anidasos $s \varepsilon$ meba ne ho atena

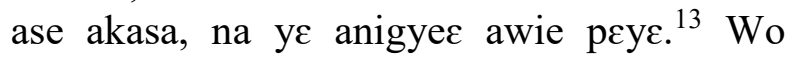
nuabaa a beayi no he mma he kyea wo.

Nkyerekyer\&mu/Mpensempensemu

Afei twercfo o he wiee ascm titire a nti otwerc

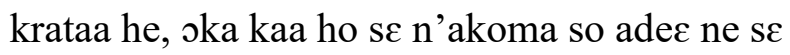
obehu n'atiefos he anim (nky. 12). Na nka

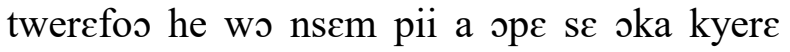
agyidifoo he, nso oyoo n'adwene se ontwerc ne nyinaa saa krataa yi mu na mmom obeko be nkyene ne be akotena ase adi nsem foforo yi ho nkommo. Nea ska de twa krataa yi to ne $s \varepsilon$, "Wo nuabaa a beayi no he mma he kyea wo" (nky. 13). come to see you and talk with you face to face, so that our joy may be complete. ${ }^{13}$ The children of your elect sister greet you.

\section{Commentary}

Having accomplished his purpose of writing the letter, the writer ends by expressing his desire to see them and speak to them face-to-face (v. 12). The writer had much more that he wanted to say to these believers but decided that he would not write everything to them in a letter but to speak about these things when he visited. He ends his short letter with the statement "The children of your elect sister greet you."

\section{CONCLUSION}

This paper has contributed to the development and promotion of African mother-tongue biblical hermeneutics and theologizing. Other studies can be conducted in this area using this paper as a basis. The paper also serves as teaching material for grassroots participation in studying the text discussed (2 John). The study has established that God is the source of all true knowledge. Whatever knowledge contradicts what God teaches is false and deceptive and must hence be rejected. From the findings, it can be concluded that the incarnation of Christ and the basic truth about God's salvific plan are uncompromisable as far as Christianity is concerned. The contemporary church must therefore stand for the truth and use the teaching ministry to counter false teachings. Finally, it can be concluded that while Africa hospitality and communal worldview are supported by Scripture, one must be careful not to be influenced negatively through association with others. A relationship that can potentially affect one's faith (in Christ) negatively must be avoided unless the believer is mature enough to withstand such influence and eventually convert the unbeliever.

\section{ABOUT AUTHOR}

Isaac Boaheng is an ordained minister of the Methodist Church Ghana, a Translator with the Bible Society of Ghana, and a lecturer at the Christian Service University College, Ghana. Boaheng holds a Master of Divinity degree from the Trinity Theological Seminary, Accra, Ghana, he has recently completed a $\mathrm{PhD}$ program (awaiting graduation) at the University of the Free State, South Africa, where he also serves as a Research Fellow. Boaheng has over fifty publications in Translation Studies, Systematic Theology, Biblical Studies, Methodist Studies and African Christianity, among others. 


\section{BIBLIOGRAPHY}

Barker, Glenn W. 2 John: The Expositor's Bible Commentary, vol. 12 edited by Frank E. Gaebelein. Grand Rapids, MI: Zondervan, 1981.

Carson, D. A. and Moo, Douglas J. An Introduction to the New Testament. Nottingham: Apollos, 2005.

De Young, James B. 1-3 John: Baker Commentary on the Bible. Edited by Walter A. Elwell Grand Rapids, MI: Baker Books, 2008.

Haas, C., De Jonge, M. and Swellengrebel, J.L. A Handbook on the Second Letter of John: UBS Handbook Series. New York: United Bible Societies, 1972. (Electronic edition).

Hodges, Zane C. 2 John: The Bible Knowledge Commentary: New Testament, edited by John F. Walvood and Roy B. Zuck. Colorado Springs: David C. Cook, 1983.

Kruse, Colin G. The Letters of John: The Pillar New Testament Commentary, edited by D. A. Carson. Grand Rapids, MI: William B. Eerdmans Publishing Company, 2000.

Ngewa, Samuel. 2 John: African Bible Commentary, edited by Tokumboh Adeyemo. Nairobi: WolrdAlive, 2006. 